DOI: $10.14451 / 2.158 .7$

\title{
ПРОБЛЕМЫ СТАТИСТИЧЕСКОГО УЧЕТА КРИМИНАЛЬНЫХ АБОРТОВ В РОССИЙСКОЙ ИМПЕРИИ В НАЧАЛЕ ХХ ВЕКА
}

\author{
(c) 2021 Воронина Галина Александровна \\ доцент кафедры «Гуманитарные дисциплины и английский язык» \\ Каспийский институт морского и речного транспорта филиал ФГБОУ ВО «ВГУВТ» \\ E-mail: gavoronina@mail.ru
}

В статье анализируются статистические данные о преступном плодоизгнании, зафиксированные в данных медицинских учреждений в Российской империи. Указывается на неточность и не полноту этих данных в связи с невозможностью подсчета совершенных преступлений, из за их латентного характера. Анализируется отношение медицинской общественности к проблеме плодоизгнания.

Ключевые слова: криминальный аборт, медицинская статистика, уголовное преступление, латентное преступление, уголовная ответственность.

В отличие от норм современного законодательства, рассматривающих прерывание беременности как право женщины, которое она может реализовать либо, исходя из собственных побуждений, либо по социальным или медицинским показаниям, будучи ограниченной лишь в сроках его реализации, для права Российской империи совершение аборта представляло собой противоправное уголовно наказуемое деяние. Религиозная догматика относит плодоизгнание к преступным деяниям, поскольку согласно ей человек является личностью с момента зачатия, и соответственно аборт это убийство.

Известный русский криминалист Н.А.Неклюдов отмечал, что «изгнание и истребление плода подлежит к разряду таких деяний, преступность которых далеко не разделяется общественным мнением, признается не всеми законодательствами, совершается тысячами, а преследуется едва, едва единицами» [1 С. 260].

По мнению другого русского дореволюционного ученого: данное преступление «не связано с определенными социальными условиями, не свойственно какой-либо социальной группе»; это явление, бесспорно, интернациональное и внеклассовое. Вопрос о том, как распределяется это деяние внутри отдельных национальностей и классов - остается открытым, т.к. настоящей статистики, не существует [2 С. 110].

В Российской империи аборт, или «искусственный выкидыш», был наиболее известным способом вмешательства в процесс деторождения. Он был широко известен как в городах, среди наиболее образованных слоев населения, так и в деревнях. Отношение к нему было не однозначное так по наблюдениям народоведа Е.Т.Соловьева, народ смотрел на изгнание плода народ смотрит как на тяжкий грех [3 С. 4].

В то время, как отмечает В.В.Розанов, на медицинских факультетах и на акушерских курсах это «преступное искусство» преподавалось открыто. ученый считал, что следовало бы с кафедры и печатно, не учить преступному» [4 С.178]. С другой стороны, криминальный аборт, как правило приводил к смерти женщины, в связи с чем медицинская общественность, опираясь на имеющиеся статистические данные, неоднократно на медицинских съездах поднимала вопрос об изменении государственной политики в отношении абортов и признании медицинского аборта, законным [5].

К 1910 годам число «искусственных выкидышей» в городах становится ощутимым, однако полные достоверные сведения об их количестве отсутствуют, что было вызвано общей тенденцией желания скрыть данное преступное деяние [6 C.41].

Поскольку в Российской империи ответственность за аборт несла как женщина, так и лицо его осуществлявшее, данное преступление обладало высокой степенью латентности и число осужденных за «искусственный выкидыш» оставалось низким, и практически неизменным [7 C.13]. Поэтому судить о степени распространенности данного преступления объективно не представляется возможным.

Единственным возможным способом проанализировать число преступных выкидышей 
был анализ данных о поступающих в больницы женщинах, заболевания которых были связаны с совершением нелегального аборта. Число таких пациенток, как отмечалось в научной медицинской литературе, того времени резко возросло. В Москве и Санкт-Петербурге количество женщин поступивших в больницу с различными осложнениями после проведения им криминального аборта в 1910 году возросло по сравнению с предыдущими годами на 33\%, а по данным родильного дома г. Саратова количество таких пациенток возросло на 16\% [6 С.42]. При этом необходимо учитывать, что в статистические данные попадали только те аборты, которые повлекли за собой серьезные медицинские осложнения, и для их лечения потребовалось квалифицированное медицинское вмешательство, те же которые не повлекли за собой медицинских осложнений, в статистику не попадали. Анализируя медицинскую статистику того времени, и в частности статистику выкидышей, известный русский хирург В.П.Федоров, считал что в большинстве случаев причиной выкидыша являлись попытки проведения криминального аборта [8 C. 42].
А.А.Гинзбург приводит статистику числа искусственных выкидышей по городу СанктПетербургу. В Санкт-Петербургском родовспомогательном заведении число выкидышей с 10\% в 1904 г. увеличилось до 17\% в 1909 г.; в Петропавловской больнице с 12\% в 1906 г. до 30\% в 1909 г. По данным Клинического Повивального Института «число выкидышей за последние 15 лет увеличилось в 10 раз. В Обуховской больнице за 1910 г. был 1331 выкидыш» [9 С.38-39].

Статистические данные, приведенные в исследованиях ведущих русских юристов конца XIX - начала XX вв. дают основание полагать, что плодоизгнание чаще всего совершалось женщинами в возрасте 40-45 лет. Однако, по нашему мнению, приводимые в исследованиях статистические данные не отражают полной картины преступной деятельности по плодоизгнанию, поскольку не все принятые к рассмотрению дела были доведены до своего логического завершения, а также в связи с невозможностью подсчета совершенных преступлений, в связи с его латентным характером.

\section{Библиографический список}

1. Неклюдов Н. А. Руководство к Особенной части русского уголовного права. Т. І. Преступления и проступки против личности. СПб.: типография П.П. Меркульева, 1876.

2. Олейник М.Л. Преступный аборт в доктрине и законодательстве // Исаев М. М. Труды кружка уголовного права. СПб., 1913.

3. РГИА. Ф. 950. ОП. 1. Д. 273. Л. 4 об.

4. Розанов В.В. Теперь и прежде. Сочинения. М.: Правда, 1990. Т. 1: Религия и культура.

5. Третий съезд Общества русских врачей (Пироговский) в С.-Петербурге (3-10 января 1889 г.): Полный отчет. СПб.: Журнал «Практическая медицина», 1889; Дневник 3-го съезда Общества русских врачей в память Н. И. Пирогова / Под ред. проф. В. В. Пашутина. СПб., 1889.

6. Демографическая модернизация России, 1900-2000 / Под ред. А. Г. Вишневского. М.: Новое издательство, 2006.

7. ернет М.Н. Аборт в законе и статистика абортов // Аборты в 1925 году. М.: ЦСУ СССР, 1927.

8. Демографическая модернизация России, 1900-2000 / Под ред. А.Г. Вишневского. М.: Новое издательство, 2006.

9. Федоров В.П. К вопросу о лечении выкидышей: 12-й Пироговский съезд: Отдел акушерства и женских болезней, 3-е заседание (отчет) // Русский врач. 1913. № 29. 